\title{
4 \\ Courting Bees in a Divided Land
}

'Bees are people', Agus had told us not long after we had arrived in Kupang back in April. This was the first fact I learnt about this animal (Apis dorsata) and its relationship to humans. In most years, April brings with it the end of the monsoon, yet, even though it was already mid-April when we had arrived in the province along the border area, heavy rain was still falling. Ironically, in a land often beset by drought and associated famine, the extended rainy season had delayed the blossoming of trees and brought its own kind of famine this year. 'Rai salaen,' said Hiro, who was also in Kupang to meet us ('The land is hungry'). The ordinary Tetum and Tetum Terik word for hunger is hamlaha; however, here the high Tetum Terik term for hunger, salaen, is paired with rai, the term for land (and all that it is associated with). The utterance 'rai salaen' conveys Hiro's highest respect for the subject under discussion.

Unlike Agus, Hiro had never been a laku. For one thing, he did not have the gregarious disposition that laku seem to require. The outlandish charisma of the laku was not the style of this regal and reserved more senior brother. Hiro had once been a foot soldier in the Indonesian army, during which time he had to fight against another brother, cousins and uncles who were fighting for FALINTIL. Now settled in the fertile valleys of his ancestral lands, just inside the Indonesian side of the border, he is a rice farmer and the extended family's cattle herder. From his fields and forest walks with the cattle each day, he can see clearly the mountains inside East Timor where his three older brothers were born, and where one of them still lives and another is buried. 
This year, as the season transitioned from wet to dry, Hiro spent his days herding in the forest, watching carefully for the first signs of the bees' arrival. As he explained to me, he looks out first for the blossoming of a range of eucalyptus flowers, then waits to see if some bees appear in the land. These first bees, he explained, were the 'intel' agents sent ahead by the main colony to report on the state of the land and the prospects for the season's bounty. In a good season, by the time the bee swarms arrive the land will be filled with the scent of blossom.

The extended rains had interrupted the blossoming process and the wani (bees) had failed to enter either the land or the trees in their usual number. 'Rai salaen,' Hiro said again. The land is hungry. He later expanded on another reason for this hunger. The people in this area of the border were now mainly farming rice and neglecting to plant the full variety of their more traditional agricultural crops like maize, beans, millet, sorghum, sweet potatoes, cassava and other root crops as well as pumpkin whose flowers are sought out by bees. I asked Hiro where the bees would be coming from. 'From somewhere else,' he said, 'from other forested lands across the island.'

Waiting for the bees to arrive had given us the chance to explore parts of West Timor and Oecusse. Reaching Atambua (Tetum Terik: Atanbua) and the international border in early May, we were hopeful that we had been able to coincide our visit with the seasonal honey harvest. Balthasar had now joined us on the border. We were in the mountainous village of Lookeu, within the kingdom of Lookeu, where Balthasar's paternal grandfather and his people had fled in the early twentieth century after being forced out of Portuguese Timor by the colonial state. Earlier, during a war in 1896, the colonisers had destroyed the Lookeu Palace and centre of government inside Portuguese Timor.

In the house built by Balthasar's parents, we were introduced to the village head, Kanis, a young man educated in Kupang and a nephew of Balthasar. We chatted over coffee and biscuits and betel nut as people started to arrive to greet the oldest son of the last king of Lookeu. (Balthasar, who lives in Melbourne, had not been home for six years.) The house was right next to the Uma Metan Lookeu, the elaborately thatched main origin house and present-day palace of the Lookeu royal family. From where we were sitting, we could just see a ridge that was obscuring what is now the international border between Indonesia and Timor-Leste (see Map 2). Mikail Asuk, one of Lookeu's ritual leaders, explained to me later that night: 'We are from Fatumea [inside Timor-Leste]. Two countries, but one ancestor.' 


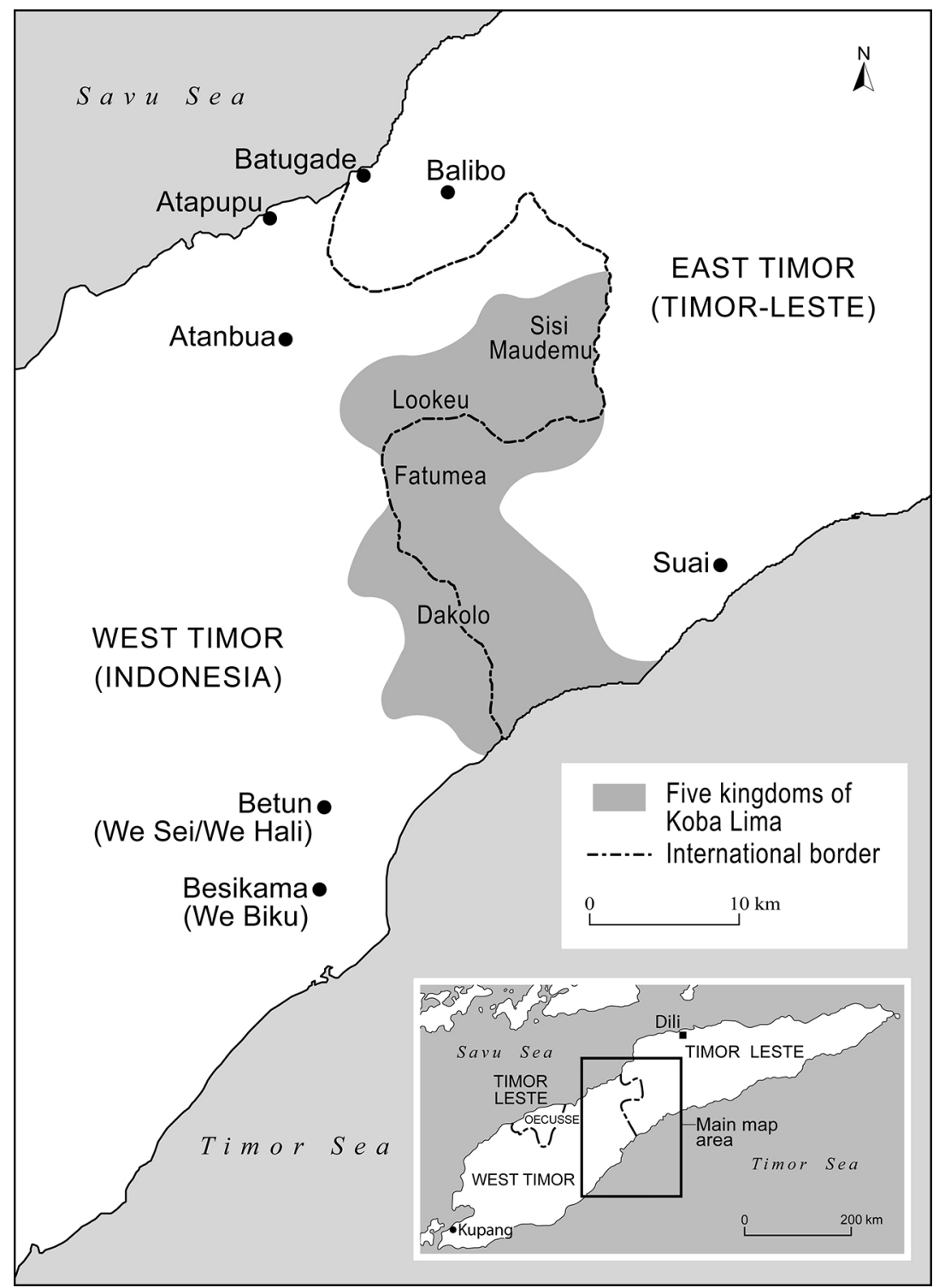

Map 2: Location of Lookeu, one of the five kingdoms of Koba Lima.

Source: Chandra Jayasuriya. 
Earlier, Balthasar had recalled the tragic circumstances of his father's movement back and forth across the colonial border:

In Dutch Timor my father was imprisoned by the Dutch, when he was still single, for his recalcitrant spirit. He later went across the border to our land and people of the Lookeu Kingdom in Portuguese Timor. He married my mother and settled in his own ancestors' land and among his own people of Lookeu. Opposing the Portuguese, he was arrested, tortured and jailed. He refused to be treated as a common man and demanded to be recognised and treated as a king in his own land and among his own people both in Dutch Timor and Portuguese Timor. He was also against the abuse of young women by the head of the Portuguese army and government in Fatumean. He refused to allow his two beautiful sisters to be used.

Not least because of this personal history, this was an emotional visit to Lookeu, a chance for those present to share stories of the past and rekindle relationships. It was also a chance to retell narratives of suffering on the border, especially during the tumultuous years following the Indonesian occupation of East Timor. Then, thousands more people fled across the border where they became caught between opposing Indonesian and FALINTIL resistance forces. Two of Balthasar's schoolmates from Indonesian Timor, suspected by the Indonesian army of being FALINTIL spies, were beheaded in front of the Uma Metan Lookeu. The beheadings were carried out using a sword gifted to Balthasar's father by an Australian solider during World War II. After the beheadings, the villagers were ordered to bury them. These stories were retold, I sensed, for at least two audiences. One was me, a foreigner; another was my husband Quin, a fellow Timorese from the far east of the island. They wanted him to know that it wasn't only those inside East Timor that suffered.

Kanis told us that there were now about 1,000 people living in the village. All of the refugees who came from East Timor in 1999 had since returned. Most of these refugees had come from Fatumean, just across the border. These people were family and the pathways are always open for them to return.

All of Balthasar's family and the other villagers in Lookeu were clearly thrilled and honoured to have him back in the village. We were taken inside the Uma Metan Lookeu and shown the house's male and female pillars where the lineage's ritual offerings are made. In 2006, when the 
house was reconstructed, the huge trees needed to fashion these two pillars had been cut down in the land of Lookeu inside Timor-Leste. From there they had been carried by hand across the border by teams of extended family members from both sides of the border. The logs were all the while adorned in male and female ceremonial attire and, by the laws of the house, they were not allowed to touch the ground until they reached the site of the origin house's construction.

After our talks and a walk around the village, including an emotional visit with village elders to the ruins of the former palace built by Balthasar's paternal grandfather during the Dutch occupation, we returned to the house and began our conversations about the upcoming honey harvest. I was told this would be a small harvest, to occur over a matter of hours, not the usual grand event where one tree might have up to a hundred or more houses and require up to seven laku and most of the night to harvest. I was introduced to one of Agus's childhood friends, Domi, who owned the wild almond tree (Irvingia malayana) that was to be harvested. He told me that his grandfather had planted the tree some 50 years earlier. Domi, like Agus, had been a laku in the past and he proceeded to regale us with humorous stories of his and Agus's youthful tree climbing and honey misadventures. (Most of the laughs came at Agus's expense.)

Later, Domi took Balthasar and me aside and quietly told us that 'the bees have names: Buik Lorok and Dahu Lorok'. Female names. (Buik is also the name of Balthasar's older sister. Dahu is the name Domi's younger sister and the name of a female cousin of Balthasar. Lorok refers to the sun, as well as to divinity or 'the enlightened one'.) Domi repeated what I had heard on my arrival in Kupang: 'the bees are people'. Their queens are Buik Lorok and Dahu Lorok and it is they-and people's relationship with them-that we were to celebrate at the honey harvest. He explained that the laku's job is to sing to the queen bees, and that through this serenade they would recognise their connections.

The songs were ritual love songs. Domi explained that they are sung to touch the hearts of these female bees and entreat them to return to their home year after year. He added that if these songs are not sung and the ceremony is not properly carried out, Buik Lorok and Dahu Lorok will not return. As proof, he told us that one of the other main honey trees in Lookeu had its 40 hives improperly harvested during the last honey season and, consequently, no bees had returned to it this year. Harvesting properly means harvesting communally, with song, dance, offerings, 
ceremony and prayer, leaving in place some of the hive for its immediate rehabilitation if the bees so choose. At the end of the season, when the bees have departed, the trees would be 'cleaned' by their owners. While some of the wax is left, the old hives are removed, and the branches are smoothed off so that the queen bees and their 'houses' will return-and, it is hoped, invite other newcomers to make their 'houses' in the tree.

I had been wondering why the ritual was called hola wani (literally meaning 'to take the bees'). In Tetum, while you can say hola meaning to buy, take or exchange something in a shop, you can also talk in the vernacular about 'taking' a woman or a man. This means to secure a wife or a husband through the marital exchange of specific cultural goods and communal ceremony. I wondered what it meant for people to hola wani (take bees)? Was there some kind of marriage-like exchange happening here between people and bees? After all, I had been told that bees are people. Now I knew the songs sung were highly poetic love songs, intended primarily for the female bees. And the laku were demonstrably the most charismatic, brave and agile of men.

Back in the village, as I pondered these musings, an unseasonable heavy rain began to fall. I knew that such unexpected 'natural' events are usually linked to ancestral intervention; they happen for a reason. I enquired into the significance of this event. 'It is bringing us matak malirin [a greening coolness].' The ancestors were rejoicing that the oldest son of the last king had returned.

Prior to the honey harvest, Balthasar had participated in a ceremony to welcome him back to the house. This ceremony also involved as many of his siblings and their children as were able to attend. Collective participation would ensure the prosperity and good health of the entire lineage. On the night of the ceremony, we began by making offerings at the family graveyard close to a ridge that obscured the international border. There, family members lit candles, prayed and sang at the graves of their ancestors. One grave belonged to Balthasar's paternal great-grandfather, Moruk Kehi, the king of Lookeu who fought against the Portuguese in 1895. But only his head was buried there; his body was buried at the place of his death in Portuguese Timor. Also in this grave was Moruk Kehi's wife, Sawak Funan, the queen of Kowa (in Balibo). Other graves held Balthasar's grandfather, who had founded the present village of Lookeu, and Balthasar's parents. 


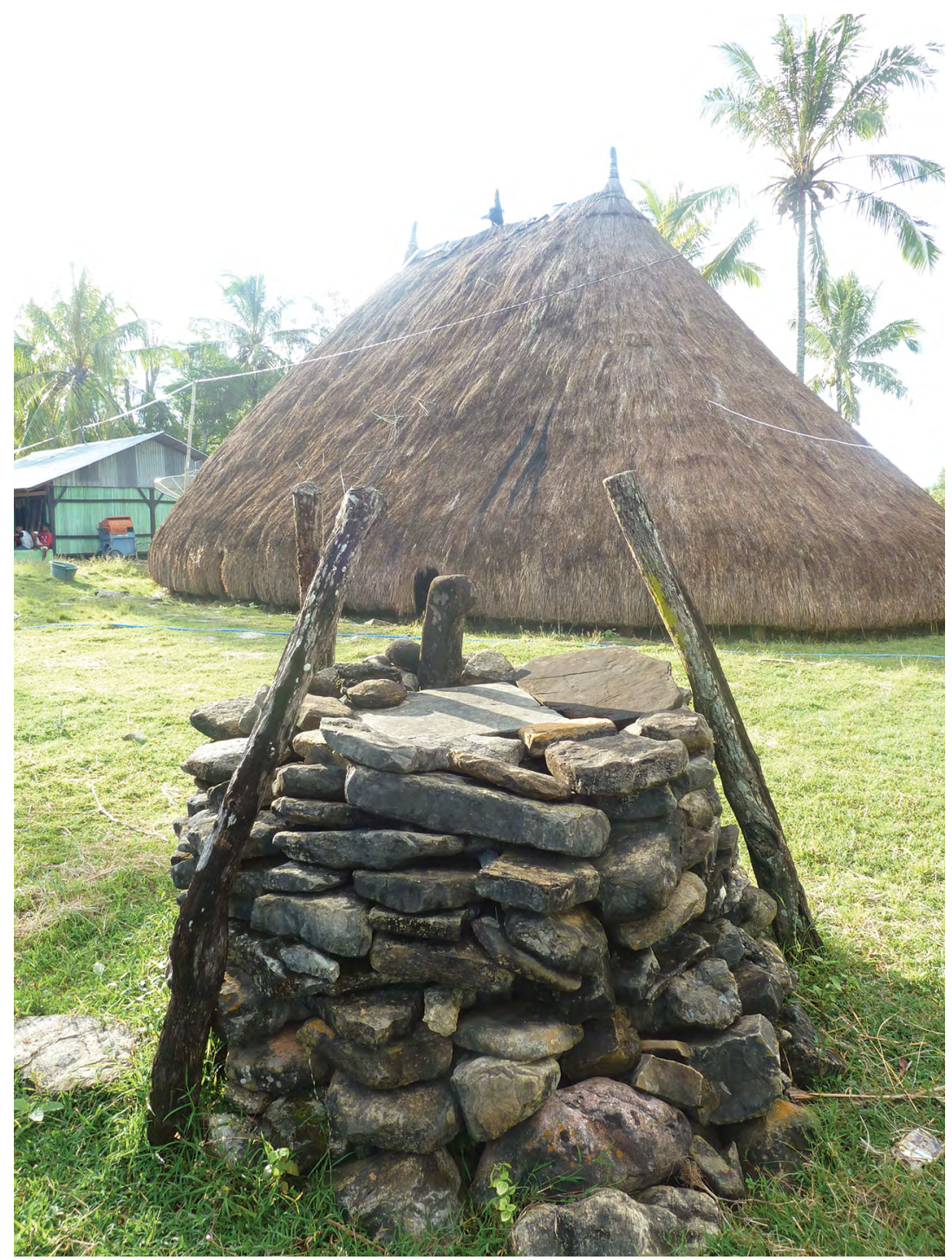

Photo 15: The palace of Uma Metan Lookeu.

When we finally entered the palace of Uma Metan Lookeu, the first offerings made at the male and female pillars were areca nut and betel leaf. The men sat on the male side of the house and the women on the female side. Baskets with betel offerings were placed in other sections of the house, including on the border between the male and female division and the outside altar. These offerings honoured the connection between Balthasar's lineage and the kingdom's mountains, fields and springs. After an hour or 
so, a group of young men carried a medium-sized black pig up the ladder into the house. It was slaughtered over the entrance door and its various body parts became part of an elaborate ritual and feast. Later, the presiding ritual leader, Mikail Asuk, mixed droplets of the pig's blood into a paste with betel chew. Beginning with Balthasar as guest of honour and ending with us (the visitors), each was called to enter the male part of the house where Mikail Asuk blew his breath onto our foreheads and pressed onto our sternum and forehead small portions of the potent paste. This was to ensure that Balthasar and all those in his company would exit the house with matak malarin - a greening coolness and flourishing life energy.

At that time, it was well past midnight and Madalena and Zeca were fast asleep in the car, but then someone mentioned that the children's heads had clipped the thatch as they had entered the house via an opening in its low thatched roof, the edges of which extend almost to the ground. Such contact is lulik (forbidden) and elders were worried for their spiritual safety. So, before parting company for the evening, Quin and I accompanied one of Balthasar's brothers to wake the sleeping pair. We roused them just enough that they could properly receive their blessing of greening coolness. Any danger following from their inadvertent breach of protocol had been ameliorated.

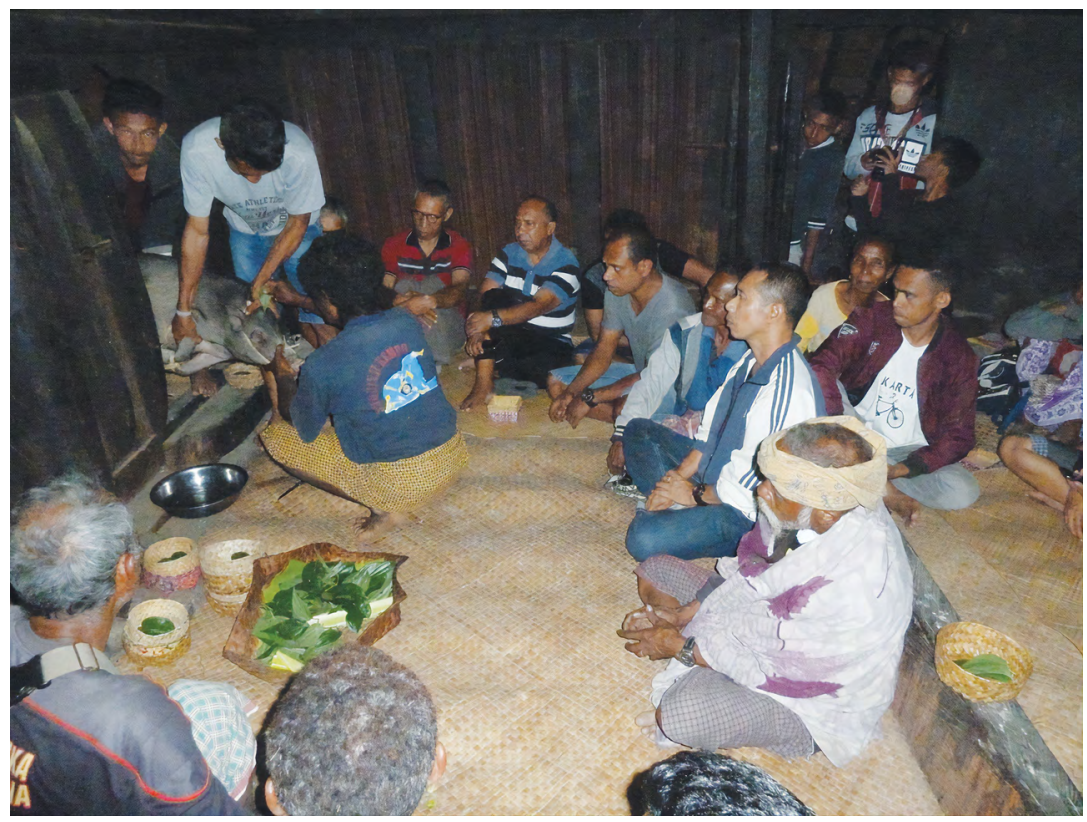

Photo 16: Ritual inside Uma Metan Lookeu. 
After a few hours sleep we were out in the forest with Hiro, Domi and the other laku, cutting bamboo for the evening's harvest. First, we cut the wild bamboo that, with its thorny side branches, makes a perfect ladder to ascend tall trees. Next, we cut and segmented another kind of bamboo that would be used to cook the harvest offerings of rice, beans, meat and bee larvae. Then we removed bark panelling from two blossoming eucalyptus trees so as to fashion the trays required to knead and strain the honey. Finally, we cleared the area around the forest stone altar where the food and honey preparation would take place.

As our party rested by the altar, I decided to ask Hiro more about the nature of the relationship between people and bees. As I was formulating the question, as if from nowhere, the senior ritual leader, Mikhail Asuk, emerged imposingly from the forest. Balthasar took the opportunity to question him on my behalf, and Mikhail smiled wryly, saying: 'They descend from one people, but of these things we cannot speak; we must be silent.' I was a little crestfallen. 'Don't worry,' Balthasar reassured me. 'Hiro knows these things and we can ask him later.'

In the meantime, Mikhail explained to us his role in the evening's harvest ritual:

The bees and the honey harvests go back to the time of our ancestors, but I cannot climb like a laku. When the honey harvest season comes, I travel everywhere around here. When the time comes for the bees to arrive in our land, the owners of the bee trees will ask me to come and call the bees. I will also be asked during each harvest to attend so that then I can communicate with them and ask them to come back next year. This skill is gifted to certain of us in Lookeu.

The bees come each year to Lookeu from named places: from the Turiscai mountains of the Mambai-speaking people in East Timor, and from the lands and mountains of the Dawan-speaking people around central north-west and central-south of West Timor. 'The bees from Turiscai are small,' Mikhail said, 'just like the people who also live in that part of the island.' Before he rose to take his leave, he remarked that the bees we would meet during the night are also warriors. 'Our ancestors prayed to them and used them in war,' he said. 


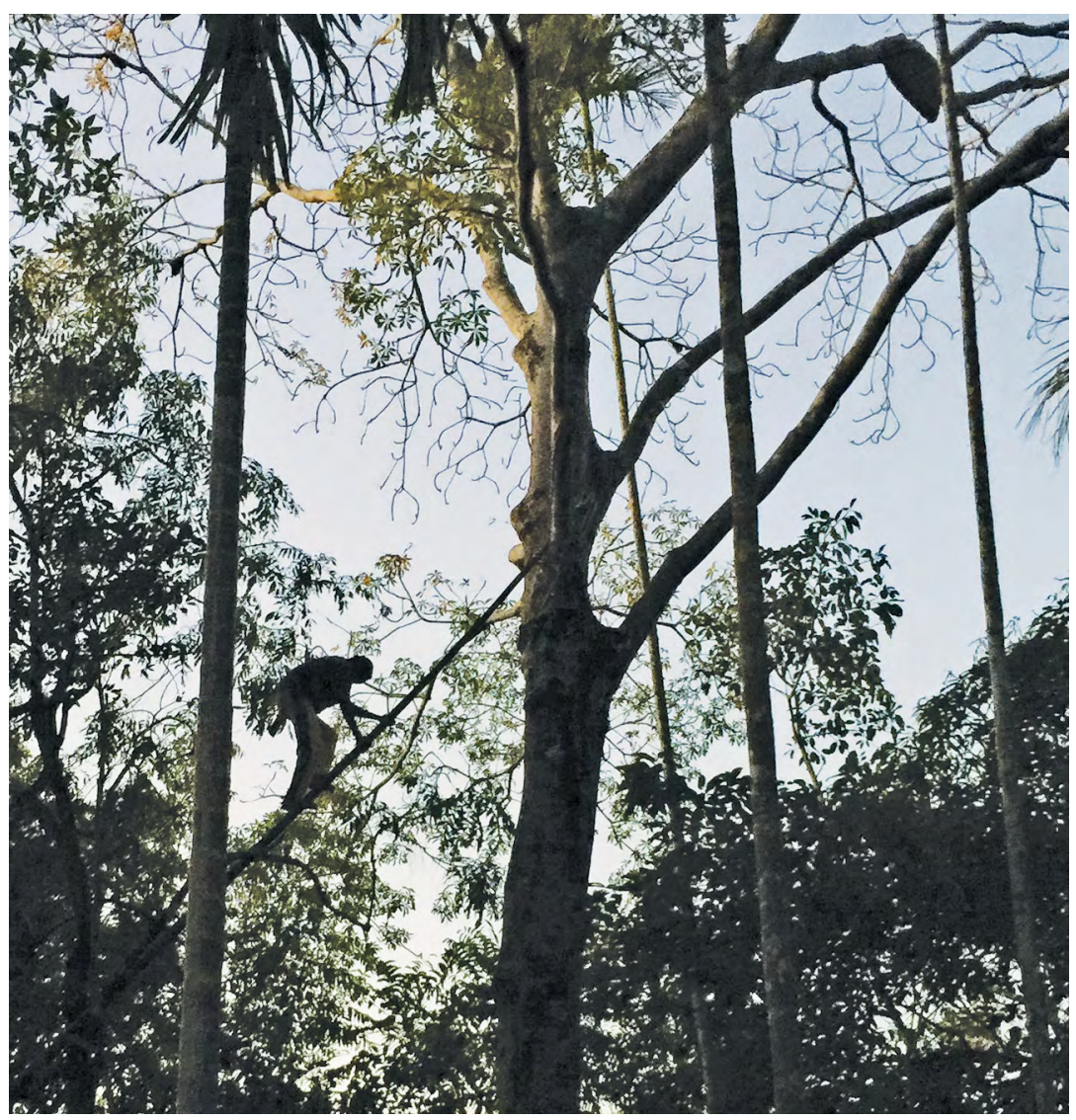

Photo 17: A laku begins his climb.

As night began to fall, people began to emerge through the darkness into the light of the fire by the forest altar. The three laku who would climb this evening had already tied the bamboo ladder to the tree. They had attached it using forest vines to lash it to the top of a small tree from where it was laid crossways and strapped to the upper trunk of the much taller honey tree. The set-up looked precarious. When the first laku leapt across to try it out, he ensured his success by singing out to the bees at the top of his lungs-something that both gave him courage and let all in the vicinity know that the harvest was about to begin. Back at the forest altar, the bark honeycomb tray and a palm-fibre filter had been positioned so that the honey would flow along it and down through a bamboo halfpipe into the plastic honey bucket below. Smooth-flowing honey would indicate the night's successful harvest and signal the life blessings to flow forth through the community from the bees. 




\section{Photo 18: The black stone basket offering.}

Dozens of villagers were now gathered in the forest. They began to prepare the 11 offering baskets and assorted ritual adornments that would be presented to the bees prior to the harvest. Among the offerings was the fatuk metan (black stone) basket specifically for the queen bees, Buik Lorok and Dahu Lorok. One of the senior men wrapped this basket carefully in a black cloth and adorned it with five corn-sheath cigarettes. The pungent smell of these hand-rolled cigarettes would entice the bees down from the tree during the evening's harvest.

Once the black stone basket had been prepared, we carried it in procession to the base of the tree where it was further adorned with morten (a red coral bead necklace) and belak (golden breast plate). Another two of these ritual objects were hung from a notch on the trunk of the tree.

One of the laku assumed his role as lead singer of the offering party. As he stood at the base of the tree, he began a resounding sacred love song to the bees. Soon he was joined in chorus by many others who held hands around the base of the tree. The linking of hands reflected both their bonds to each other and with the bees. The singers circled the tree three times, exhorting:

Ooooh ... ooooh ... ooooh ... fatuk metan [black stone] ... eeeeh ... the wild almond tree where you hang yourselves, where you come to dwell. You came together here as a group to make your home ... We bid you a farewell ... do come next year. Tonight, we are here with you, our generous and respectful lovers, Dahu 
Lorok and Buik Lorok. You are giving us your sweetness and the strength of your bodies. We are here to thank you and to bid goodbye to you while hoping and pleading for you to return next year. To return here to your home so we shall be together again for another night. So that we can taste your sweetness and the strength of your beings ... Do kindly share your experience in this home to others and bring them along next year, too.

As the singing and movement concluded, the laku held aloft the black stone basket and rotated it in the air in the three directions from where the bees had come, and to where they would return.

The deep emotion of the serenade resonated through the forest and our bodies. The excitement was building. Next, a small black pig that had been tethered to a stake nearby was carried across to the base of the tree for offering. Domi, the honey tree's owner, rubbed the animal with betel leaf to give it the blessing of life, before another man respectfully and skilfully slit the pig's throat and drained the blood into a bucket below. Domi moved in the shadows between the pig and tree base, collecting drops of the blood with betel leaf, which he rubbed around the trunk of the tree and over the various other ritual offerings. When it was done, the offering baskets and the dead pig were carried back to the forest altar.

Now the laku were ready to climb. Lulled into an unhurried sense of time during the day's slow preparations, we realised that we had quite suddenly reached the climax. We scurried back to the forest altar where we had left our bags, and the children and I put on protective clothing that someone had presciently suggested we purchase the day before in the district capital of Atambua. Everybody else, including Quin, remained in their shorts, sarongs and t-shirts. 'Don't worry,' I was told, 'bee bites are like medicine. They make you stronger.' In the ensuing hours, I would come to be so thankful for my recently purchased blue plastic raincoat, matching pants and camouflage ninja mask.

When the laku started to ascend the trees and began to vocalise, all was fine at first. We stood and watched, awestruck but calm, from the forest floor. 'Ooooh,' sang out the laku:

We have prepared the rope to climb ... we have tied the bamboo ladder ... we are on our way up ... you are all hanging up there waiting for us ... ooooh ... our beloved, enlightened Dahu and Buik Lorok. 


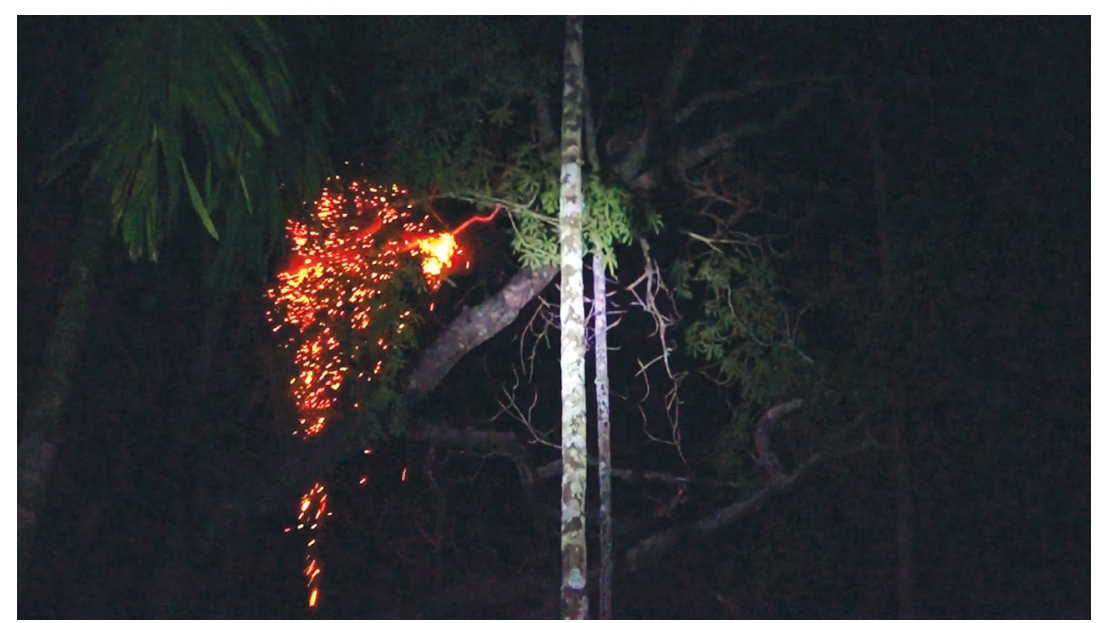

\section{Photo 19: Honey harvest fire blooms.}

The laku's song was, however, soon punctuated by hissing sounds as their firesticks, now alight, brushed against the first of the hives hanging down from the branches above. The sparks from this contact flashed out spectacularly into the darkness, forming wide blooms of red before beginning their descent to the forest floor. This, I had been told, was cue for the bees to do the same: to follow the light of the sparks, to descend and lie quietly on the forest floor so that their remaining sweetness could be harvested.

Because we were also filming the event, we were using torchlight to enable the recording. As a result, the bees were now also flying en masse towards this alternative source of light_-and anyone standing near it. What felt and sounded like rain on my plastic jacket was a hail of bees. They came in waves, in unison with the work of the firesticks above. By this point, I was filming mostly with my eyes tightly shut, as everyone was yelling out for us to do. I would sense when each subsequent wave was arriving by the intense bodily reverberations and smell that would precede them. This olfactory cue would then be quickly augmented by the sharp pain of searing hot needles piercing my gloved, camera-holding hands. Mikhail's words rang through my head: 'These bees were also used by our ancestors as warriors.' This truly felt like a war zone. 
But when the camera was not in use and the torches were switched off, peace returned to the forest floor. We would be serenaded again by the red blooms and the ritual love songs of the laku. The peace was punctuated by the occasional calls from old men on the ground, entreating the laku to secure a date for next year with their beloved bees. Alternately, keen for the harvest to be filmed, these same senior men would periodically call out to admonish the other ground-dwellers to stop their banter. 'Be quiet! We are SHOOTING,' they would yell. All during their exchanges, a pulley system of buckets was being used to convey the honeycomb from the high branches to the ground, where a small team of men were waiting to collect it and, amid the swarming bees, carry it off to the forest altar.

Most people, including our two children, had now retreated to the forest altar about a hundred or so metres from the tree. Some sat chatting by the fire; others were helping to cut up the pig and cook the various cuts of meat with rice and beans in specially fashioned bamboo cylinders. One old man had the job of kneading and straining the collected honeycomb, while others stood by to watch how it flowed. These tasks were in full swing by the time we returned to the altar with the laku and the last of the comb. The people seated by the fire were happy; their reading of the pig's liver was positive and so all was in order. Just as importantly, the kneaded honey was flowing well along the bark, through the fibre strainers, down the bamboo half-pipe and into the bucket. These were auspicious signs for the agricultural year ahead.

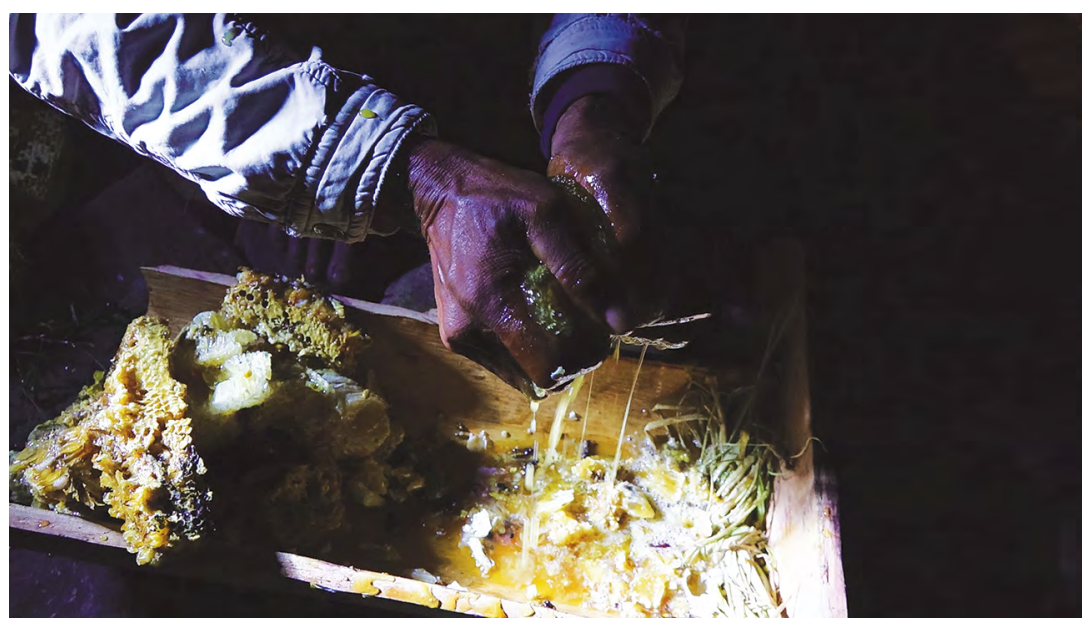

Photo 20: Straining the honey. 
After the offerings had been prepared and laid out in each of the 11 offering baskets, we carried them back to the base of the tree. All of the baskets except the black stone basket with its betel nut and cigarettes had been filled with rice, beans, meat and slivers of the harvested honeycomb and bee larvae. The bees were still hovering around the base of the tree, and they swarmed us again. I had been sweating profusely inside the plastic raincoat and hadn't realised we would be heading back into the war zone, and so I had prematurely taken off my protective clothing. 'Don't worry,' the others told me again. They explained that if we held the right attitude and composure the bees wouldn't sting (much) and those that did would give us a dose of medicine, making us stronger. This time it worked; I didn't get a single sting.

After we had honoured the bees and their spirit custodians by placing the cooked offerings at the base of the tree, we picked up the baskets and returned to the forest altar. There we all sat and ate together by the firelight before each receiving a piece of the life-blessed betel nut to take home. We collected up the remaining honey, beeswax and larvae-filled combs and carried them back through the night to Domi's house where the spoils of the harvest would be shared out among all involved.

In the past, this honey would be shared among families, sometimes traded with others. We had been told that there is now a thriving commercial market for wild honey. If the honey and wax harvest is plentiful, the laku and the tree custodian, who receive the largest shares, will often sell some to Chinese-Indonesian traders in Atambua. In the modern supermarket near our Atambua hotel there was even a display of assorted honey products near the checkout, with one brand labelled 'Timor wild honey'. A $200 \mathrm{~mL}$ bottle sold for around US $\$ 2$.

The day after the ceremony, when we were back driving around Atambua, I had the chance to ask Edmund (Balthasar's youngest brother) about the white bag of honeycomb he had carried back from the tree late in the harvest. At that time, he had called out to us excitedly and pointed to the contents of the bag. 'This is the lulik [potent] one,' he had said, bringing it over so that I could film inside. 'Look at the body of that comb,' he marvelled, before pointing out the morten and belak in the same bag. 
These were the same two ritual objects that had been carried up into the tree by Bruno, one of the laku. Edmund explained, as if I already should have known, that this was an act of fo folin (giving value), a process used to describe the ritual goods given in marriage exchange by a male house to the house of a man's bride. Here in the honey harvest, the goods had also been carried up into the tree as an offering to the female houses of the bees (and later brought down again, with the very best of the honeycomb). Hola wani, I then realised, meant 'to court bees'. What we had just participated in was an age-old Timorese process of courtship, only this time it was of bees, and the ritual took place in a divided land.

The painful pairing of courtship and division in the practice of hola wani reveals the consequences of history. Although these types of honey harvest ceremonies were once carried out right across island Timor, it is only in the most remote and mountainous areas that the practices continue. Wars and displacement since the imposed colonial division in 1859, deforestation and changes in land use and crop composition are rapidly changing the island landscape and its attractiveness and carrying capacity for bees. Ironically, the suffering and displacement experienced by the Lookeu community along both sides of a remote and once dangerous mountain border has also kept others out and allowed the survival of relatively intact forests that are so essential for their continued relations with wild honey bees. Through the ritual of hola wani, the people on the border of island Timor demonstrate both their determination to maintain the bees' movement across the region and to preserve their shared identity. ${ }^{1}$

1 The 30-minute film documenting this harvest is called Wild Honey: Caring for Bees in a Divided Land. It is distributed by Ronin Films. 
This text is taken from Island Encounters: Timor-Leste from the outside in, by Lisa Palmer, published 2021 by ANU Press, The Australian National University, Canberra, Australia.

doi.org/10.22459/IE.2021.04 